\title{
Miranda
}

Revue pluridisciplinaire du monde anglophone /

Multidisciplinary peer-reviewed journal on the English-

speaking world

15 | 2017

Lolita at 60 / Staging American Bodies

\section{The patterning of obsessive love in Lolita and Possessed}

\section{Wilson Orozco}

URL: http://journals.openedition.org/miranda/11234

DOI: 10.4000/miranda.11234

ISSN: 2108-6559

\section{Publisher}

Université Toulouse - Jean Jaurès

\section{Electronic reference}

Wilson Orozco, "The patterning of obsessive love in Lolita and Possessed", Miranda [Online], 15 | 2017,

Online since 06 October 2017, connection on 16 February 2021. URL: http://journals.openedition.org/ miranda/11234 ; DOI: https://doi.org/10.4000/miranda.11234

This text was automatically generated on 16 February 2021.

\section{(c) (i) () $\Theta$}

Miranda is licensed under a Creative Commons Attribution-NonCommercial-NoDerivatives 4.0 International License. 


\title{
The patterning of obsessive love in Lolita and Possessed
}

\author{
Wilson Orozco
}

\section{Introduction}

1 Nabokov's work is well known for its complexity and its convoluted plots, something which is particularly true of Lolita, which is rich in patterns, repetitions and mises en abyme. The latter take the form of intertextual relations, references to painting, popular culture or cinema (and, in fact, Nabokov's relation to the cinema has been the subject of many papers and books). Two films are mentioned in the novel: Possessed and Brute Force. In what follows, a comparison will be made between the former and the novel in terms of the repetition of the obsessive love present in both works. Humbert and Louise are obsessive lovers and their obsessions paradoxically lead them to develop aggressive feelings towards the beloved-to the point of physical violence or at least the phantasy of it. Those obsessions are also a manifestation of their mental instability, something which makes them extremely unreliable narrators in a context of a confession they make, resulting in the text we read or the film we see. While Humbert explains and justifies his acts in his confession, however, Louise is made to talk to a psychiatrist. The purpose of this analysis is to find common patterns in the novel and the film in the terms of obsessive love, hostility towards the beloved, madness, unreliable narration and confession.

\section{Patterning in Lolita}

2 Authors like Fraysse (2008) and Bouchet (2010), the latter especially in her "analysis of embedded structures and meta-artistic devices in Lolita," have studied what, thanks to them, now appears evident: the patterns implicit in Nabokov's work and first pointed out by Appel Jr. (2012). These patterns are, for him, a manifestation of Nabokov's involuted narrative-apparent in his writing because "[an] involuted work turns in 
upon itself, is self-referential, conscious of its status as a fiction, and [...] allegorical of itself [...]" (Appel 2012, xxiii). Besides:

Nabokov's passion for chess, language, and lepidoptery has inspired the most elaborately involuted patterning in his work. Like the games implemented by parody, the puns, anagrams, and spoonerisms all reveal the controlling hand of the logomachist; thematically, they are appropriate to the prison of mirrors. (Appel 2012, xxviii)

3 All of the above, that is to say, parody, puns, anagrams and spoonerisms are characteristics of Lolita. It is, therefore, no wonder that reading this novel is a challenging experience. For her part, Bouchet states, with regard to that involution, that Lolita "also provides embedded structures that function as typical mises en abyme" (Bouchet 13), that is, elements which mirror the whole or some part of the novel. Such mises en abyme can also be understood as the work-within-the-work described by Alfred Appel Jr. as the "self-referential devices in Nabokov, mirrors inserted into the books at oblique angles" (Appel 2012, xxix).

\section{Cinema as mise en abyme}

4 The use of popular culture, and of film in particular, are examples of the mises en abyme mentioned above. In fact, Lolita could be categorized as a kind of encyclopedia of popular culture in the form of cinema, songs, advertising, etc., making it one of the most surprising and complex works of art of the $20^{\text {th }}$ Century. The presence of cinema in Nabokov's work is particularly important. It has been analyzed primarily by Appel (1974) and Wyllie $(2003,2005,2015)$, the latter offering a specific study of formal filmic devices and the stylistic recreations made by Nabokov's narrators (2003). ${ }^{1}$ These motifs could in fact be examples of mises en abyme, repetitions, doubles and mirrors, which, along with confinement, are recurrent in film noir too. ${ }^{2}$ Signs of self-reflexivity in Nabokov's work are, as noted earlier, usually made evident through the use of cinema:

This notion of participating in a self-declared and acknowledged piece of creative artifice has since been acknowledged as a key element of the overall cinematic aesthetic, but it was also to become a recurrent theme of Nabokov's Russian and English fiction. (Wyllie 2003, 14)

And as "Nabokov's characters [...] take their cinema-going seriously" (Wyllie 2005, 222), we can understand why Humbert and Lolita are such obsessive moviegoers. In the case of Humbert, it enables him to have the chance of stealing Lolita's affections, and in Lolita's case, of indulging in her passion, dreaming of someday becoming one of the film stars she sees on the screen, just like Margot in Laughter in the Dark (Nabokov 1989). But, most importantly, cinema in Lolita appears not only at the level of content but also at a formal level:

Nabokov's excitement [with film] parallels the fervor with which many of his protagonists pursue their cinematic dreams. This 'keenness' also extends to his manipulation of the processes, styles, and techniques of film-making in his fiction, which both generates a thematic context for the preoccupations of his movieobsessed characters and introduces a new narrative and perceptual dimension that impacts upon fundamental notions of time, memory, mortality, and the imagination. (Wyllie 2005, 217-218)

6 Lolita contains constant references to cinema in the form of movies alluded to without mentioning their titles, something which led to the critics making guesses. Tadashi 
Wakashima (n.d.), for example, identified one such film as John Ford's The Quiet Man (1952) - a movie which does not fit the narrative time in Lolita, but which is nonetheless alluded to in Humbert's once destroyed but rewritten diary:

Thursday. Last night we sat on the piazza, the Haze woman, Lolita and I. Warm dusk had deepened into amorous darkness. The old girl had finished relating in great detail the plot of a movie she and L. had seen sometime in the winter. The boxer had fallen extremely low when he met the good old priest (who had been a boxer himself in his robust youth and could still slug a sinner). (Nabokov 2012, 45)

There are also allusions to cinema in the movie magazines Lolita reads (Bouchet 5), and comparisons and descriptions in the book are often film-based-for example Charlotte is constantly compared to Marlene Dietrich. So, it is no surprise that with such an emphasis on cinema, the novel attracted an early and very successful film adaptation by Stanley Kubrick (Agirre 15).

\section{Explicit Films in Lolita}

8 Humbert Humbert, like every good romantic hero (see Manolescu), gives us detailed insights into his thoughts and feelings, whether deriving from a cold landscape or from what he finds in hotels or reads in newspapers. The journeys he makes seem to be a repetition, clearly separated in time. Repetitions, by the way, are abundantly present in Nabokov's work, particularly in Lolita. As Boyd explains:

What enabled Nabokov to explore pattern in time in entirely new ways was the gradual mastery he acquired over the recombination of fictional details. He transmutes a recurrent element sufficiently for the repetition to be overlooked, he casually discloses one piece of partial information and leaves it up to us to connect it with another apparently offhand fact, or he groups together stray details and repeats the random cluster much later in what appears to be a remote context. (Boyd 300)

Those repetitions could, for instance, take the form of the journeys Humbert and Lolita made together. Evidently the most painful moment for him is when he loses his Lolita and starts looking for her and Quilty. In this Lolita-less journey, he offers plenty of literary and geographical data, besides news of current events. But he finally gets tired of searching and decides instead to go to The Enchanted Hunters hotel, the place where he was the happiest of men with the nymphet, just to practice what he knows best: remembering. He goes back to that paradigmatic place because a "curious urge to relive my stay there with Lolita had got hold of me. I was entering a phase of existence where I had given up all hope of tracing her kidnapper and her" (Nabokov 2012, 261). But as Humbert prefers reading to "reality," he changes his mind and goes to the local library to check the events of that fatal summer when he was in The Enchanted Hunters almost as a fugitive: "Anyway, I was literally gasping for breath, and one corner of the book of doom kept stabbing me in the stomach while I scanned and skimmed...Brute Force and Possessed were coming on Sunday, the 24th, to both theatres" (Nabokov 2012, 262). This is, to say the least, curious and paradoxical. of the two hundred-odd films which Humbert claims to have seen with Lolita, only those two titles are actually mentioned, and both of them are in fact real films: Brute Force was directed by Jules Dassin (1947) and Possessed by Curtis Bernhardt (1947). In any case, there is no doubt that Nabokov (as well as his characters) took cinema seriously. He even indicates that he bore the aforementioned films in mind expressly for the purpose of the novel: "I saw both [of 
them], and thought them appropriate for several reasons. But I don't remember why... [...]. I guess I should have said more about them" (cit. in Appel Jr. 1974, 210). Appel Jr. also states that both movies have a lot to do with the novel because "the titles gloss H.H.'s circumstances, and Brute Force-a prison film, which Nabokov thought he had seen-is thematically apt" $(2012,436)$. But, given the hypotexts found in Lolita, especially those involving feelings of idealization, hostility towards the beloved, his or her disappearance and a subsequent obsession, only Possessed will be taken into account for the purposes of the present analysis. ${ }^{3}$

\section{Possessed}

10 Possessed is the narration Louise makes to a psychiatrist about her obsessive and unrequited love for David and her subsequent killing of him. At the beginning of the story, David only sees in her the chance to have some fun. He is more interested in worldly and artistic pleasures, and sees Louise's demands to marry him as a burden, until he finally tells her it's better for them to break up. Louise ends up alone, considering the attachment to her beloved man the greatest of her obsessions. At the same time she works as a nurse, taking care of Mrs. Graham, who thinks Louise and her husband Dean are having an affair. As a result of this belief, she ends up committing suicide by jumping into a lake. She apparently suffered from delusions, the same delusions we find later on in Louise. Dean, along with his two children, Wynn and Carol, together with Louise, go to live in Washington. Some time later, Louise sees David and, as that disturbs her again, she takes the decision to quit her job in order to escape from him. But as Dean is secretly in love with Louise, he asks her to marry him. Louise accepts but makes it clear that she doesn't love him. In the end, David and Carol fall in love and plan to get married. This makes Louise angry to the point of killing David-to abort, in a way, his plans.

11 One structure Possessed and Lolita have in common is that of the love triangle. David doesn't love Louise, he loves Carol, and Louise doesn't love Dean, she loves David, in the same way as Humbert doesn't love Charlotte but her daughter, and Lolita doesn't love Humbert, but Quilty. The person loved obsessively is at the end absent, and a confession is made at the beginning of the story to explain the reasons for that absence. So, in order for that explanation to be possible, a jury or a psychiatrist have to be brought in to advance the telling of the story. As Gabbard and Gabbard observe, "psychiatric consultations have offered filmmakers the perfect device for unearthing dark secrets and simplifying exposition" (Gabbard \& Gabbard 6). Both Louise and Humbert have ended up in psychiatric hospitals, with Humbert the more expert habitué of them, even playing sarcastically with his "carers" by inventing dreams just to have the pleasure of listening to the interpretations derived. In this respect, the novel differs greatly from the film. In other words, while Louise is made to talk through narcosynthesis, Humbert laughs at psychiatry (which is, furthermore, a recognized Nabokovian trait; he famously hated Freud and psychoanalysis). Another difference is the place of narration. Although both narratives are set in enclosed spaces, while Louise tells her story from a psychiatric hospital (because of the breakdown ensuing from her having killed David), after having killed Quilty, Humbert writes from prison the text we have in our hands. And he has shot his enemy after making us believe during the novel that he was about to kill other characters (Valeria, Charlotte, Mr. 
Schiller, and even Lolita). This is similar to Louise, who, in her state of delusion, made us believe she shot Carol, although the actual victim turns out to be David. In any case, the shootings at the end of both narrations are a common element to both novel and film.

Thus, Possessed contributes to these patterns in Lolita that relate to the tendency of Humbert to present hypotexts that have to do with tragic love, something which is rewritten, of course, by the Lolita hypertext, if we accept Genette's palimpsestual theory (1997), in which literature is nothing more than the recreation or rewriting of previous literature as parody and pastiche. The link between Lolita and these "tragic" hypotexts has been analyzed extensively by Appel Jr. (2012b), who looks, for example, at the recurrence of Poe's work in Lolita, and, especially, the famous link between the American poet's “Annabel Lee" and Humbert's Annabel Leigh. Elsewhere, Fraysse (2008) and Proffer (1968) highlight the misleading hypotext of Prosper Merimée's Carmen (2011). ${ }^{4}$ Likewise, Wyllie (2000) examines the relationship between one of the songs Lolita sings and the Carmen hypotext. As the song goes:

And, o my charmin', our dreadful fights.

And the something town where so gaily, arm in

Arm, we went, and our final row,

And the gun I killed you with, o my Carmen,

The gun I am holding now.

(Drew his .32 automatic, I guess, and put a bullet through his molı's eye.) (Nabokov 2012, 61)

The song could be a parody of an actual song that also deals with killing the beloved, perhaps the classic Frankie and Johnny in Sam Cooke's 1947 version:

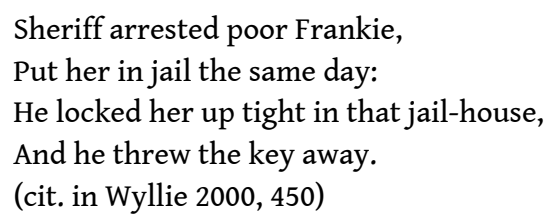

The full lyrics contain similar elements of love, betrayal, obsession and revenge. These elements are also found in Possessed and particularly in Lolita:

Not only is this rendition of Frankie and Johnny significant in its relevance to the novels plot, but also in its thematic elements, particularly its cinematic style and its associations with the American Western and gangster movie, which are to feature in Humbert Humbert's depiction of Quilty's murder: '(Drew his .32 automatic, I guess, and put a bullet through his moll's eye.).' The theme of revenge is also central to Humbert Humbert's scenario, reaffirming the sense of him as the innocent wronged, and thus justifying his actions. (Wyllie 2000, 449)

The traits of the aforementioned hypotexts give both Possessed and Lolita a certain noir atmosphere, which Wyllie specifically examines in the novel:

Most distinctive is Humbert Humbert's assumption of the role of noir hero, the figure faced with a dilemma [...]. Humbert Humbert plays out this role most explicitly in his revenge scenario, which is introduced by the allusions to gangsters and molls in his 'Carmen' song [...], and concluded at the end of the novel when he runs his Melmoth into a ditch [...]. (Wyllie 2005, 225)

16 To this we have to add another common element: a final scene in which the killer or mourner retells the story and reconstitutes the beloved one through a text, whether written or filmic. 


\section{Madness, confession and unreliable narrators}

One characteristic shared by Humbert and Louise is that they both suffer a loss of balance, which we learn about little by little. In Louise's case, it includes a change in her physical appearance. She goes from being an elegant and polite woman, representing "tenderness" (as David puts it) to someone who ends up looking like a psychopath killer, as the following stills from the film show: ${ }^{5}$
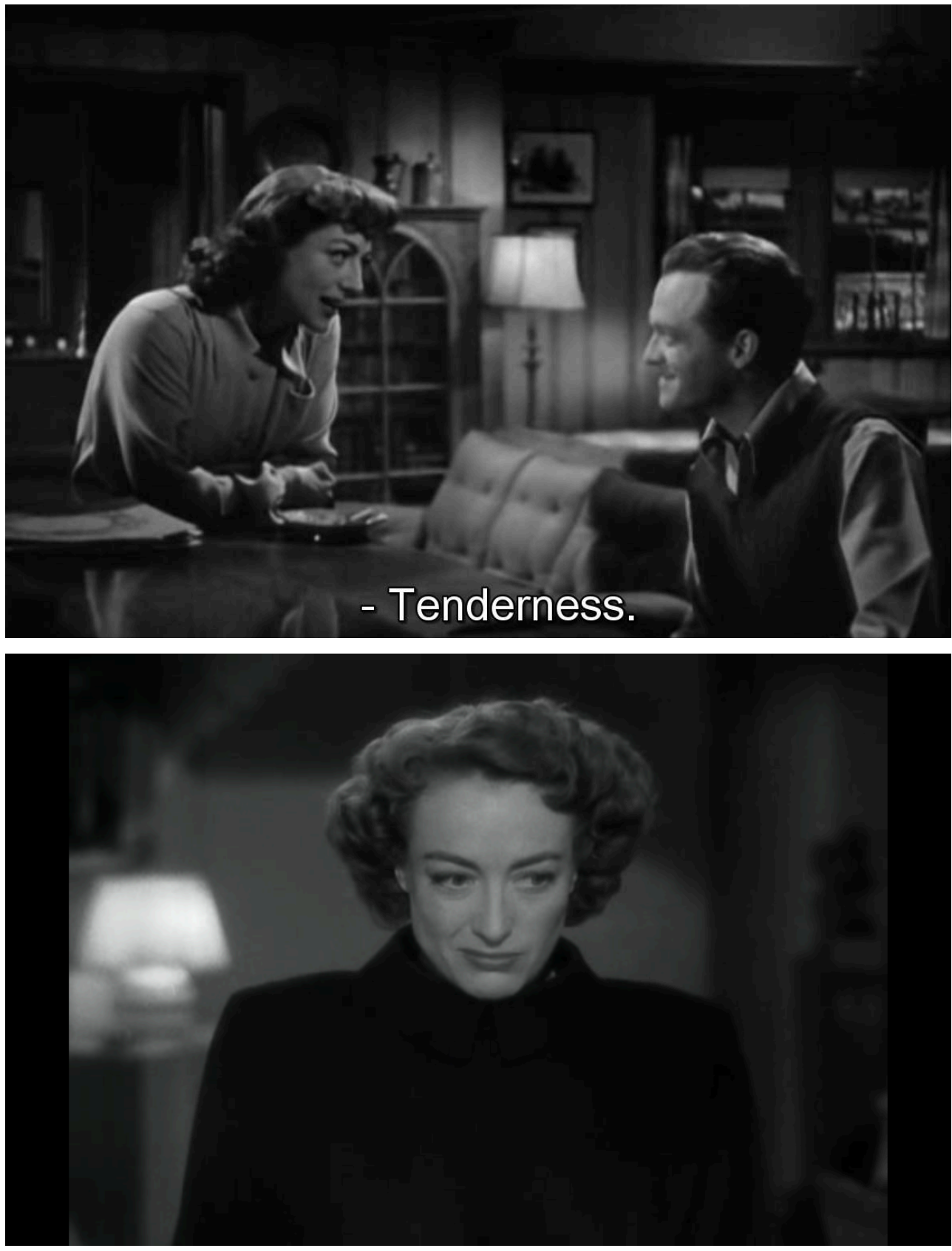

Humbert too undergoes a transformation, in his case from homme de lettres to murderer -something even he admits: "You can always count on a murderer for a fancy prose style" (Nabokov 2012, 9). Thus, he anticipates a possible ending at the beginning of the novel. The combination of writer and killer makes him the typical "rational" killer so 
present in Poe's work -an author he seems to admire. Here Chesterton's definition of madness could help us to understand Humbert's behavior:

"Everyone who has had the misfortune to talk with people in the heart or on the edge of mental disorder, knows that their most sinister quality is a horrible clarity of detail ; a connecting of one thing with another in a map more elaborate than a maze. If you argue with a madman, it is extremely probable that you will get the worst of it ; for in many ways his mind moves all the quicker for not being delayed by the things that go with good judgment. He is not hampered by a sense of humour or by charity, or by the dumb certainties of experience. He is the more logical for losing certain sane affections. Indeed, the common phrase for insanity is in this respect a misleading one. The madman is not the man who has lost his reason. The madman is the man who has lost everything except his reason. (Chesterton 73)

In both stories, mental illness also seems to be present, appearing from the start in the form of possession. Humbert sees himself as a nympholept who behaves as if a greater force were in control of his life (and he makes us believe that is the case). This trait is also present in noir films, in which characters are "sometimes Caught, sometimes Possessed, often Spellbound" (Sanders 101). In both characters, possession implies an absence of moral responsibility, since both are driven by something which they cannot control. In this sense, the title Possessed itself displays a rich semantic isotopia: it refers, for example, to the classic relationship between madness and possession. This relationship is made apparent in Lolita when Humbert believes he is possessed because he is a victim of the devil's scheme: "[...] for all the devil's inventiveness, the scheme remained daily the same. First he would tempt me -and then thwart me, leaving me with a dull pain in the very root of my being" (Nabokov 2012, 55).

Humbert and Louise also experience possession as lovers. Louise is possessed by madness, not by David (which in psychoanalytical terms would represent a significant narcissistic wound). At the same time, David is possessed by Louise in death, as if killing the beloved were the way to possess him or her forever. When the beloved has been lost or has disappeared, possession also takes the form of an obsessive, persistent repetition of their names. Humbert, on the one hand, constantly repeats my Carmencita or my Lolita. Louise, by contrast, does not use the possessive adjective, because she certainly does not see David as her creation as Humbert does with a textual Lolita. It is still interesting, however, to note how she constantly repeats his name: "David? I'm looking for David...David? David, I've been looking everywhere for you, [...]" (Bernhardt) while she wanders the streets of Los Angeles aimlessly just before being interned in the hospital. She repeats his name around six times, the same number of times she shouts it at the end when she finds out she has killed him as shown here in this expressive fade which mixes the shooting with her screams: 


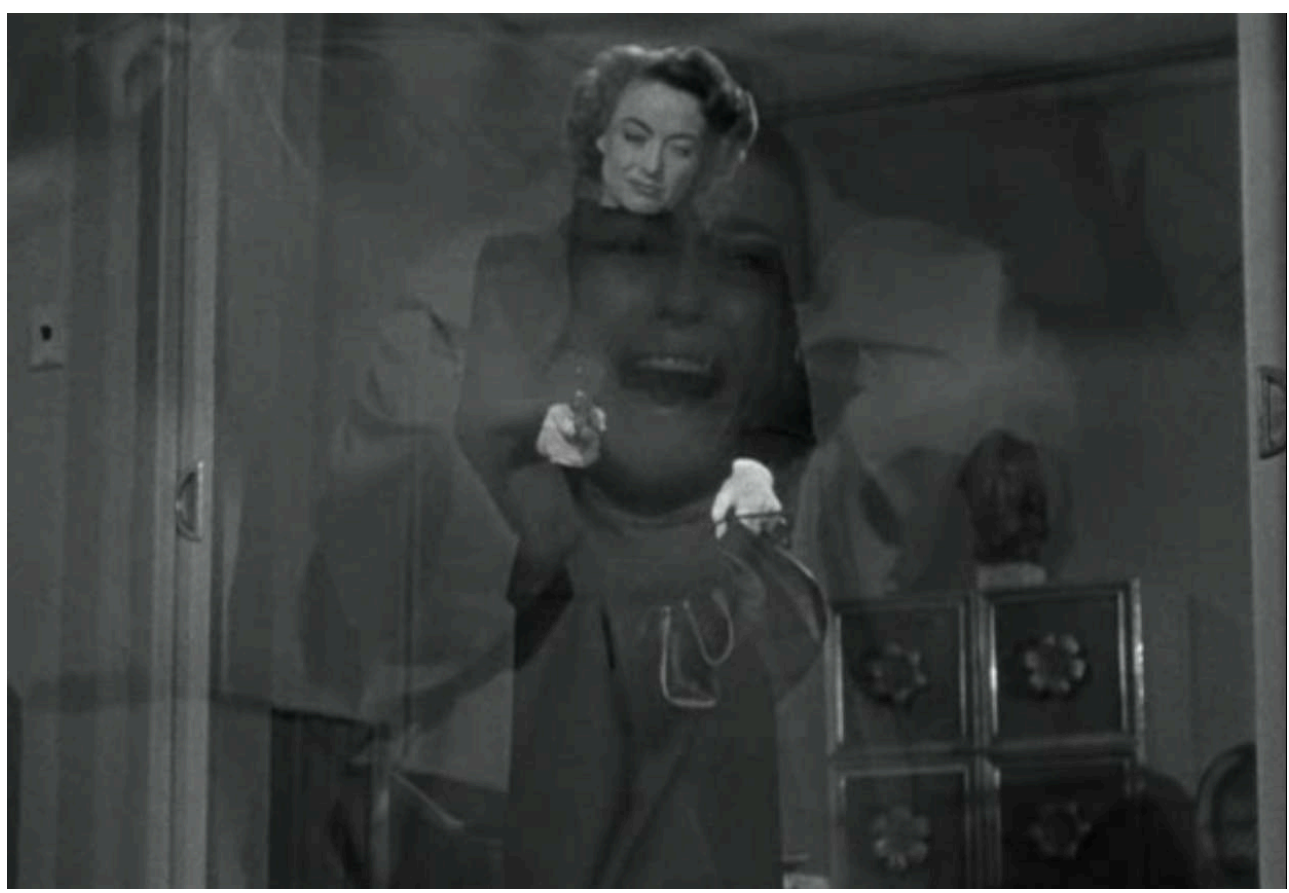

21 That screaming of the name causes her to go into a deep sleep, denying reality. David is now pure nostalgia, just a reason for the existence of the movie. Those desperate screams correspond to Humbert's, who also somewhat hysterically repeats "Heart, head -everything. Lolita, Lolita, Lolita, Lolita, Lolita, Lolita, Lolita, Lolita, Lolita, Lolita. Repeat till the page is full, printer" (Nabokov 2012, 109). And the realization that he will love Lolita forever leads him to make his final confession in which he manifests his true love: "I am thinking of aurochs and angels, the secret of durable pigments, prophetic sonnets, the refuge of art. And this is the only immortality you and I may share, my Lolita" (Nabokov 2012, 309). Lolita is also the first and the last word of Nabokov's novel, just as Possessed begins and ends with the name, David. That recurrence expresses the fact that the text we read -or see- is an attempt to reconstitute the loved one who has disappeared, and both texts, filmic and written, are an excuse to bring him or her back. Film and novel end up being about David and Lolita, a homage to both lost loves. Finally, possession is evident at the textual level too, as Humbert at one point states: "What I had madly possessed was not she, but my own creation, another, fanciful Lolita" (Nabokov 2012, 62). Therefore the nymphet will be possessed forever in the text while David will be possessed in Louise's memory. In other words, a possessed Louise has possessed him, whereas Humbert has possessed Lolita too-first physically and then finally for eternity in the text we read. ${ }^{6}$

If both characters are possessed by mental instability, who, then, is in charge of the diagnosis? With regard to the novel, in the preface it is the editor, John Ray, Jr., who offers his views on the text and on Humbert himself. He has edited the text, placing himself above it, organizing it and making omissions: we read what he lets us read. And he was chosen to be the editor because, as he states, he was the author of "a modest work ('Do the Senses make Sense ?') wherein certain morbid states and perversions had been discussed" (Nabokov 2012, 3). That is why he brands Humbert's pages as "strange" (3) and links Humbert's case with psychiatric studies:

at least $12 \%$ of American adult males -a "conservative" estimate according to Dr. Blanche Schwarzmann (verbal communication)- enjoy yearly, in one way or another, the special experience "H.H." describes with such despair; that had our 
demented diarist gone, in the fatal summer of 1947, to a competent psychopathologist, there would have been no disaster; but then, neither would there have been this book. (Nabokov 2012, 5) specularizable" (Doane 221). For that reason, Gabbard \& Gabbard point out that this kind of film also "appropriates psychiatry as an important element in women's search for identity" (Gabbard \& Gabbard 53). In fact, Louise's treatment is so paternalistic that the psychiatrist gives his verdict long before he has listened to her, diagnosing her as an "intelligent" but "frustrated" woman. And in sexist and patriarchal terms, this frustration has to do with unrequited love or the loss of the beloved man. As Doane insists, the diagnosis is depicted "as over-possessiveness, as a relentless desire for a man who no longer loves [a woman]" (Doane 209). In other words, Louise wants to possess her lover but at the same time she is possessed by something stronger than her, and so she needs to be observed by the male psychiatrist. Finally, according to Doane, we also witness that the "woman's narrative reticence, her amnesia, silence, or muteness all act as justifications for the framing of her discourse within a masculine narration" (Doane 216). The psychiatrist, for example, constantly offers justifications for his necessary intervention:

Ten years ago I could have prevented this. Five, even two years ago, it could've been prevented. It was there for any psychiatrist to see. 
[...]

It's a clear case of psychosis. Completely unbalanced [...]. We human beings act according to certain patterns of behavior. Sometimes, why exactly we don't know yet the pattern is broken, the wires are crossed, the mind cannot evaluate, judge, or even function properly. Shock follows shock, until eventually the mind gives way. The brain loses control and the body sinks into coma. Then in a biblical sense we might say that such a person is possessed of devils and it is the psychiatrist that must cast them out. (Bernhardt) consider is the nature of Humbert and Louise's narration-one which is characterized by unreliability and which is defined in general terms by Chambers as "misreporting, misreading, misevaluating, underreporting, underreading, underregarding" (Chambers147). The product of such narrations will manifest itself in "unindentified interlocutors, erased events, the collapse of one voice into another" (Chambers 149)all traits common to postmodern narration (Shen \& Xu 45). In Possessed, that unreliability is displayed when Louise refuses to reveal all of her secrets. After the doctor has asked what her name is, why she is in Los Angeles and why she is running away from it, Louise immediately goes on the defensive, clarifying to the doctor that she is not going to tell everything.

partial? In this context, another point to consider is that Louise's flashbacks sometimes reach the point of hallucination. There is a constant confusion in her narration because she appears to experience things which then prove to be false, such as when she seems to have killed Carol because of her engagement to David, something which proves to be part of her delirium. On the other hand, the nature of Lolita's text is quite undetermined: it was written in prison by Humbert in just a few weeks, then passed to a lawyer, and then passed to an editor who makes modifications. Humbert, the man who loves to lie, includes a diary in the novel-a diary he once had to destroy and which he presents to us as rewritten from memory. In other words, there is an evident indeterminacy of the real truth of Lolita's text.

\section{Conclusions}

We are presented here with two unreliable narrations concerning an obsessive love, the whole story told, in the confessional mode, and in a long analepsis, to a psychiatrist in the case of Possessed, and to the members of a jury in the case of Lolita. Both the psychiatrist (as in Hitchcock's Psycho) and the editor in Lolita are figures that exist at a meta-textual level, explaining and reordering the story, and interpreting the mental state of the narrators. Both versions are in this way articulated by an authoritative figure who seems to have the last word. Furthermore, confession is at the heart of both film and novel. Thus Humbert must tell his dreams to psychiatrists (although he invents them), and he has had to previously confess his past loves to Charlotte. Finally he ends up making a long confession in prison where he reveals, "I am writing under observation" (Nabokov 2012, 10). However, one big difference between film and novel is 
that in Lolita psychoanalysis and psychiatry are subjected to sarcasm and ridicule. In Humbert's case any contact he had with psychiatry was not sought out, whereas near the end of the film the psychiatrist affirms the value of psychiatry and justifies its intervention in the case of Louise.

31 At the beginning and at the end of both works, we find the beloved's name mentioned in a desperate call: David and Lolita. The film therefore fits the main isotopies of the novel as a specular motif: feelings of aggressive hostility, the theme of the dead or missing lover, obsession, mental instability, confession, unreliable narration and remembering someone beloved. ${ }^{7}$ Besides, both novel and film share a common noir atmosphere because

Noir themes and moods include despair, paranoia, and nihilism ; an atmosphere of claustrophobic entrapment; a nightmarish sense of loneliness and alienation; a purposelessness fostered in part by feelings of estrangement from one's own past even as one seems driven to a compulsive confrontation with that past. Film noir presents us with moral ambiguity, shifting identities, and impending doom. Urban locales give noir films authenticity, adding texture to their psychologically dense and convoluted plots. (Sanders 92)

The irony in both texts is that what is loved the most ends up being destroyed or annihilated. Humbert makes us believe he will kill Lolita, but he actually kills Quilty. Louise makes us believe she killed Carol, but the victim actually turns out to be David. In this sense, one of the main topics of both film and novel is the "crime of passion". In both of them the character who is killed is also one of the elements of a love triangle: Louise kills her ex-lover so he cannot marry Carol ; Humbert kills Quilty for having stolen his Lolita. In the end, both Lolita and Possessed are manifestations of art at the service of love, even if those characters end up hurting what they love the most -as Nabokov expressed so masterfully in much of his work (Montero 19).

---. « Popular music in Nabokov's Lolita, or Frankie and Johnny: a new key to Lolita ?» Revue des études slaves 72.3-4 (2000): 443-452. Print.

\section{BIBLIOGRAPHY}

Agirre, Katixa. « Lolita de Vladimir Nabokov: historia de una obsesión (fílmica)». Álabe 1 (2010) :

1-15. Print. 8 Sept 2017 <http://revistaalabe.com/index/alabe/article/view/1/2>

Appel Jr., Alfred. Nabokov's Dark Cinema. Nueva York: Oxford University Press, 1974. Print.

---. « Notes [to The Annotated Lolita]». The Annotated Lolita. Londres: Penguin Modern Classics, 2012. 319-456. Print.

---. « Preface, Introduction [to The Annotated Lolita]». The Annotated Lolita. Londres: Penguin Classics, 2012. v-lxvii. Print.

Bernhardt, Curtis. Possessed. Warner Bros., 1947. Film. 
Bouchet, Marie. " "The Enchanted Hunters and the Hunted Enchanters: The Dizzying Effects of Embedded Structures and Meta-Artistic Devices in Lolita, Novel and Film"». Sillages critiques 11 (2010) : n. pag. Web. 4 feb. 2016.

Boyd, Brian. The Russian Years. Princeton: Princeton University Press, 1990. Print.

Chesterton, Gilbert. « The Maniac». On Lying in Bed and Other Stories. Calgary: Bayeux Arts, 2000. 71-75. Print.

Creed, Barbara. The Monstrous-Feminine: Film, Feminism, Psychoanalysis. Nueva York: Routledge, 1997. Print.

Dassin, Jules. Brute Force. Estados Unidos: Universal Pictures Distributors Corporation of America, 1947. Film.

Davidson, James A. « Hitchcock/Nabokov: Some Thoughts on Alfred Hitchcock and Vladimir Nabokov». Images. N.p., s. f. Web. 9 sep. 2015.

Doane, Mary Ann. "The Clinical Eye: Medical Discourses in the "Woman's Film" of the 1940s». Poetics Today 6.1/2 (1985): 205-227. Print.

Fraysse, Suzanne. « Worlds Under Erasure: Lolita and Postmodernism». Cycnos. N.p., 2008. Web. Gabbard, Glen, y Krin Gabbard. Psychiatry and the Cinema. Washington, DC: American Psychiatry Press, 1999. Print.

Genette, Gérard. Palimpsests: literature in the second degree. Lincoln : University of Nebraska Press, 1997. Web. 5 feb. 2016.

Hitchcock, Alfred. Shadow of a Doubt. USA: N.p., 1943. Film.

Manolescu, Monica. « Humbert's Arctic Adventures: Some Intertextual Explorations». Nabokov Studies 11 (2008): 1-23. Print.

Mérimée, Prosper. Carmen. Recuperado de amazon.com, 2011. Print.

Montero, Rosa. « Fresas e hipopótamos». Lolita. Madrid: Funambulista, 2004. 7-19. Print.

Nabokov, Vladimir. Laughter in the Dark. Nueva York: Vintage International, 1989. Print.

---. The Annotated Lolita. Londres: Penguin Modern Classics, 2012. Print.

Proffer, Carl. Keys to Lolita. Bloomington: Indiana University Press, 1968. Print.

Proust, Marcel. Albertine disparué. Paris: Honoré Champion, 1992. Print.

Sanders, Steven M. « Film Noir and the Meaning of Life». The Philosophy of Film Noir. Ed. Mark T. Conard. Lexington: The University Press of Kentucky, 2006. 91-105. Print.

Shen, D., y D. Xu. « Intratextuality, Extratextuality, Intertextuality : Unreliability in Autobiography versus Fiction». Poetics Today 28.1 (2007) : 43-87. Web.

Wakashima, Tadashi. « Double Exposure: On the Vertigo of Translating Lolita». N.p., s. f. Web. 20 may 2015.

Wyllie, Barbara. «"My Age of Innocence Girl” - Humbert, Chaplin, Lita and Lo». Nabokov Online Journal IX (2015): 23-26. Print.

---. « Nabokov and Cinema». The Cambridge Companion to Nabokov. Ed. Julian Connolly. Cambridge: Cambridge University Press, 2005. 215-231. Print.

---. Nabokov at the Movies. North Carolina: McFarland \& Company, 2003. Print. 


\section{NOTES}

1. Popular culture also serves to define the nymphet in the novel and create a distance between her and Humbert's high culture, as well as to express disgust towards Quilty, himself a film director (Wyllie 2003, 128). On the many references to popular culture, Nabokov's research into it, and especially the subtext of Charles Chaplin's life in relation to Humbert's, see Wyllie (2015). Referring to other forms of art, Wyllie states that Nabokov's narrator/protagonists "often explicitly emulate the theater, as they do painting or literature [...], but also, and at the same time, in combination with filmic images and devices" $(2003,30)$.

2. With respect to doubles, if we look carefully at some of Alfred Hitchcock's films, especially Shadow of a Doubt (1943), we can understand from their use why comparisons have been made between Nabokov and the English film director (Davidson; Wyllie, «Nabokov and Cinema»). As Wyllie also observes, apart "from their 'humour noir' Nabokov and Hitchcock shared other key characteristics -a penchant for puzzles and game-playing, a fascination with ways of seeing and voyeurism, with complex patternings of themes and imagery, doubles and doubling, and a sophisticated manipulation of narrative conventions" (Wyllie 2005, 218).

3. Appel Jr. would perhaps agree with this choice as he asserted that Possessed "is more immediately appropriate" because Humbert's unrequited love and obsession for Lolita sends him "to a madhouse a year after Lolita's departure" $(1974,211)$, which is partially the fate of Louise, the protagonist of the film. Brute Force does not provide so strongly a mise en abyme of the Lolita plot basically because of Joe Collins' relation to his beloved: there is no love triangle, he tries to escape prison to see her again and, most importantly, he has never abused her.

4. Albertine disparue (Proust) is another hypotext worth noting.

5. For an analysis of women depicted as psychopaths in films, see The Monstrous-Feminine: Film, Feminism, Psychoanalysis (Creed).

6. Allusions to physical and visual possession are profuse in Lolita: "I had possessed her -and she never knew it" (Nabokov 2012, 21); "Virginia was not quite fourteen when Harry Edgar possessed her" (Nabokov, 2012, 43) and "I knew exactly what I wanted to do, and how to do it, without impinging on a child's chastity; after all, I had had some experience in my life of pederosis; had visually possessed dappled nymphets in parks" (Nabokov 2012, 55). In terms of physical possession, Humbert believes too that "watching" is "possessing" but in a safer way.

7. And in Louise's particular case, the "dynamic interaction between the narrativization of the female patient and her inducement to narrate, to become a story-teller as a part of her cure" (Doane 217).

\section{ABSTRACTS}

Repetitions, doubles, and mises en abyme are a constant in Nabokov's work and Lolita is one of the best examples. One of those repetitions in time and space has to do with Humbert Humbert going back over the times when he was happy with the nymphet in 1947. He finds that in that year the film Possessed was premiered. If a comparison is made between that movie and the novel, both text and film seem to reflect each other. The main purpose of this article is to show that the film is a mise en abyme of the novel because both novel and film display the same pattern of obsessive love, which includes idealization, feelings of hostility, obsession with the disappearance of the 
beloved and a textual and filmic reconstitution by way of unreliable narrations through plenty of flashbacks and analepses.

Répétitions, doubles, et mises en abyme sont une constante dans l'œuvre de Nabokov, et Lolita en est l'un des meilleurs exemples. Une de ces répétitions dans le temps et l'espace est quand Humbert Humbert se remémore les événements lorsqu'il était heureux avec la nymphette en 1947. Il constate alors que cette année-là le film Possessed est sorti dans les salles de cinéma. Si l'on établit on fait une comparaison entre ce film réel et Lolita, le texte et le film semblent se refléter l'un l'autre. Le but principal de cet article est de montrer que le film est une mise en abyme de Lolita parce que les deux suivent le même modèle d'amour obsessionnel : idéalisation, sentiments d'hostilité, obsession de la disparition du bien-aimé et une reconstitution textuelle et filmique aux narrations peu fiables à l'aide de nombreuses analepses.

\section{INDEX}

Mots-clés: Lolita, mise en abyme, Possessed, motif, cinéma.

Keywords: Lolita, mise en abyme, Possessed, patterning, cinema.

\section{AUTHOR}

\section{WILSON OROZCO}

Lecturer

University of Antioquia

wilson.orozco@udea.edu.co 